JURNAL KETAHANAN NASIONAL

Vol.23, No.3, Desember 2017, Hal 300-319

DOI:http://dx.doi.org/ 10.22146/jkn.28829

ISSN:0853-9340(Print), ISSN:2527-9688(Online)

Online sejak 28 Desember 2015 di :http://jurnal.ugm.ac.id/JKN

VOLUME 23

No. 3, Desember 2017

Halaman 300-319

\title{
Inovasi Pemuda Dalam Mendukung Ketahanan Ekonomi Keluarga (Studi Di Kampung Warna-Warni Kelurahan Jodipan, Kecamatan Blimbing, Kota Malang)
}

\author{
Prisca Kiki Wulandari \\ Universitas Brawijaya \\ Email: priscakiki@ub.ac.id
}

\begin{abstract}
This study aimed to (1) analyzed the youth innovation of Muhammadiyah University of Malang student named Guys Pro in changing the slump area of RW 2 Jodipan Village; (2) analyzed the youth innovation product that was vivid village of Jodipan in supporting the family economic resilience.

This study used qualitative approach with descriptive data display. This study was discussed by Habermas' theory of communicative action and theory of family resilience.

This study showed that the innovation of Guys Pro had changed the image of slump in Jodipan village and replaced the face of village to be vivid village. The vivid village became a pilot project of tourism village in Malang. Promotion was given continually by the online and offline media which was attracting the visitor interest to came. Their visits contributed various opportunities for people to served the needs of visitiors. Recently, they became the home entrepreneurs. In addition the mothers (ibu-ibu) PKK also participate in managing the vivid village. The image changing as a tourism village in Malang supported the family economic resilience for people of $R W 2$, Jodipan.
\end{abstract}

Key Words: Youth Inovation, Guys Pro, Family Economic Resilience

\begin{abstract}
ABSTRAK
Penelitian ini bertujuan untuk (1) menganalisis inovasi pemuda mahasiswa Universitas Muhammadiyah Malang yang tergabung kelompok Guys Pro dalam merubah image kumuh RW 02 Kelurahan Jodipan; (2) menganalisis produk inovasi pemuda yakni Kampung Warna Warni Jodipan (KWJ) dalam mendukung ketahanan ekonomi keluarga.

Penelitian ini menggunakan pendekatan kualitatif dengan pemaparan data secara deskriptif. Pembahasan dalam penelitian ini dianalisis menggunakan teori tindakan komunikatif Jurgen Habermas dan teori ketahanan keluarga.

Hasil penelitian menunjukkan bahwa inovasi Guys Pro merubah image kumuh di RW 02 Kelurahan Jodipan dengan menciptakan Kampung Warna-Warni. Kampung Warna-Warni Jodipan menjadi pilot project kampung wisata di Kota Malang. Promosi yang dilakukan secara terus-menerus melalui online dan offline menarik minat pengunjung untuk mengunjungi KWJ. Kunjungan wisatawan memberikan peluang bagi masyarakat untuk menyediakan barang dan jasa yang dibutuhkan oleh pengunjung. Saat ini sebagian besar masyarakat Jodipan berwirausaha di rumah masing-masing. Selain itu, ibu-ibu PKK di RW 02 Kelurahan Jodipan berpartisipasi dalam memanajemen wisata KWJ. Perubahan image KWJ sebagai kampung wisata di Kota Malang mendukung ketahanan ekonomi keluarga bagi warga RW 02 Kelurahan Jodipan.
\end{abstract}

Kata Kunci: Inovasi Pemuda, Guys Pro, Ketahanan Ekonomi Keluarga 


\section{PENGANTAR}

Kurun waktu 2020-2045, Indonesia akan mengalami bonus demografi. Bonus demografi merupakan suatu kondisi dimana jumlah penduduk usia produktif, 15-60 tahun berjumlah dua kali lebih besar dari jumlah usia non produktif. Keadaan demikian bagaikan pisau bermata dua, apabila kebijakan-kebijakan pemerintah mendukung berkembangnya penduduk usia produktif, maka Indonesia akan mengikuti jejak negara-negara maju seperti Cina dan Jepang. Namun, apabila pemerintah dan masyarakat Indonesia gagap akan kondisi tersebut dan terlambat menyikapinya maka yang terjadi adalah sebaliknya yakni kemunduran, karena naiknya penduduk usia produktif tanpa dukungan peningkatan kualitas dan lapangan pekerjaan akan membahayakan kondisi bangsa ini. Tentunya situasi yang kedua bukanlah harapan bangsa Indonesia.

Menurut Undang-Undang No 40 Tahun 2009 tentang Kepemudaan pasal 1 menjelaskan definisi pemuda adalah warga negara Indonesia yang memasuki periode penting pertumbuhan dan perkembangan yang berusia 16-30 tahun. Perjalanan sejarah bangsa Indonesia telah banyak memunculkan pemuda sebagai aktor utama yang berperan melakukan perubahan. Organisasi-organisasi pergerakan nasional yang mengawal kemerdekan Indonesia, sebagian besar anggotanya adalah kaum muda. Pergantian dua orde (orde lama ke orde baru dan orde baru ke reformasi) juga dipelopori oleh kaum muda, khususnya mahasiswa. Oleh sebab itu, sangat diharapkan ketika Indonesia mengalami bonus demografi, pemuda menjadi garda depan sebagai agent of change sekaligus sebagai agent of solution bagi permasalahan bangsa dan negara.

Harapan sekaligus beban diberikan kepada kaum muda di masa sekarang.
Ada beberapa alasan yang mendukung mengakibatkan pemuda memiliki tanggung jawab besar dalam tatanan masyarakat. Alasan-alasan tersebut adalah (1) pemuda memiliki kemurnian idealisme; (2) pemuda cenderung berani dan terbuka dalam menyerap nilai-nilai dan gagasan-gagasan baru; (3) pemuda memiliki semagat pengabdian dan spontanitas dalam pengabdiannya; (4) pemuda memiliki segudang inovasi dan kreativitas; (5) pemuda memiliki keinginan untuk segera mewujudkan gagasan-gagasan baru; (6) pemuda memiliki keteguhan janji dan keinginan untuk menampilkan sikap dan kepribadian yang mandiri; (7) masih langkanya pengalaman-pengalaman yang dapat merelevansikan pendapat, sikap, dan tindakannya dengan kenyataan yang ada (Abdullah, 1974).

Alasan-alasan positif tersebut apabila mendapat bimbingan guna memberikan kesadaran dari generasi terdahulu, maka pemuda dapat berperan secara alamiah dalam kepeloporan dan kepemimpinan untuk menggerakkan potensi-potensi dan sumber daya yang ada dalam masyarakat (Satries, 2009). Artikel ini berusaha mengulas bagaimana kepeloporan pemuda khususnya mahasiswa Universitas Muhammadiyah Malang (UMM) dalam mengembangkan potensi sumber daya di suatu kampung, yakni kampung Juanda yang ada di Kelurahan Jodipan. Menarik untuk dikaji lebih jauh, sebab Kampung Jodipan pada mulanya merupakan kawasan kumuh, yang ada di tengah perkotaan. Berita bbc.com dalam artikelnya mengabarkan bahwa tempat tersebut merupakan kawasan kumuh nomor 2 se-Indonesia (www.bbc.com). Surya dalam artikelnya juga memberitakan bahwa pemerintah Kota Malang berniat akan menggusur warga yang tinggal di Kampung 
Juanda, dan memindahkan ke rumah susun. Akan tetapi setelah berita tersebut muncul belum ada tindakan penggusuran dari pihak pemerintah (suryamalang.tribunews.com).

Mahasiswa UMM berhasil mengubah image Kampung Juanda sebagai kawasan kumuh menjadi sebuah tujuan wisata yang sekarang dikenal dengan nama Kampung Warna-Warni Jodipan (KWJ). Suatu daerah yang dikembangkan menjadi tempat wisata akan memberikan banyak manfaat positif bagi warga sekitarnya, terutama peningkatan kesejahteraan warga. Santosa (2011) menjelaskan sektor pariwisata memiliki cakupan kegiatan yang sangat luas, sehingga peningkatan kesejahteraan dapat dioptimalisasikan dengan memperbesar multiplier efek dalam kesempatan kerja, peluang berusaha, dan distribusi pendapatan. Lebih lanjut dijelaskan, dampak yang paling terasa, terjadi pada sub sektor pariwisata primer, seperti penginapan, restoran, angkutan, hiburan dan perdagangan eceran.

Seiring dengan jumlah kunjungan wisatawan yang meningkat, maka permintaan akan produk barang dan jasa di daerah wisata akan mengalami peningkatan (Muljadi dan Warman, 2014). Baru-baru ini daerah-daerah di Indonesia mengembangkan sektor pariwisata guna mendongkrak pendapatan daerah dan sekaligus menciptakan lapangan perkerjaan baru. Hal ini juga berlaku di Malang Raya (Kota Malang, Kabupaten Malang, dan Kota Batu). Di antara ketiga tempat tersebut Kota Batu masih belum bisa disaingi dalam kemajuan pengembangan pariwisatanya. Bahwa Kota Batu memiliki jargon "Kota Wisata Batu". Akan tetapi, Kota Malang juga tidak kalah dalam pengembangan pariwisatanya. Kota Malang lebih mengutamakan pengembangan wisata kota. Tulisan ini akan membahas salah satu wisata kota yang ada di Kota Malang, yakni Kampung Warna-Warni Jodipan atau yang biasa disingkat KWJ.

Kampung Warna-Warni Jodipan (KWJ) terletak di Kelurahan Jodipan, Kecamatan Jodipan, Kota Malang. Pada awalnya, tiga RT yang ada di RW 02 Kelurahan Jodipan dikenal sebagai kampung kumuh. Lokasi yang berada di tepi aliran Sungai Brantas, dan berada di bawah jembatan memberikan image negatif terhadap perkampungan itu. Di samping itu, letak rumah-rumah yang dekat dengan sungai mengakibatkan warga dengan seenaknya membuang sampah di sungai. BBC (16 Oktober 2016) memberitakan bahwa sempat terdengar kabar bahwa perkampungan pinggir sungai di Kelurahan Jodipan akan digusur. Warganya akan dipindah ke rumah susun. Sebagian besar warga yang menempati kawasan perkampungan di Jodipan adalah pendatang. Tanah yang digunakan untuk membangun rumah merupakan tanah negara. Walaupun demikian warga tetap membayar Pajak Bumi dan Bangunan (PBB) setiap tahunnya. Dengan adanya proyek mahasiswa membuat kampung warna-warni di Kelurahan Jodipan, mengurungkan niat pemerintah Kota Malang untuk merelokasi warga. Wali Kota Malang sangat mendukung, Kelurahan Jodipan menjadi DTW (Daerah Tujuan Wisata) baru sebagai wisata kota. Inovasi mahasiswa UMM memberikan manfaat besar bagi warga di sekitar KWJ.

Beberapa hasil penelitian Haryati (2016) tentang peran pemuda dalam mengelola kawasan ekowisata dan implikasinya terhadap ketahanan masyarakat desa menunjukkan bahwa pemuda berperan hanya pada beberapa sektor tertentu dalam pengelolaan kawasan ekowisata. Di samping itu peran pemuda memberikan implikasi terhadap ketahanan 
masyarakat desa tetapi belum berjalan secara maksimal. Penelitian Saryani (2013) tentang Pariwisata dan Ketahanan Sosial Budaya menunjukkan bahwa pariwisata di Yogyakarta berkembang karena Yogyakarta memiliki citra baik di mata wisatawan, serta dukungan pengembangan sarana dan prasarana. Dampak negatif, seperti pemeliharaan objek wisata yang kurang serius, belum adanya jaminan keselamatan yang maksimal bagi wisatawan, serta krisis multidimensional masyarakat mempengaruhi ketahanan sosial budaya masyarakat Yogyakarta.

Lebih lanjut Wulandari (2015) dalam penelitiannya tentang peran pemuda dalam memperkenalkan industri kepariwisataan dan implikasinya terhadap ketahanan ekonomi wilayah menunjukkan bahwa pemuda berperan dalam promosi wisata di Kabupaten Trenggalek melalui berbagai kegiatan baik yang dilakukan oleh pemerintah ataupun nonpemerintah. Kegiatan pemuda mendukung peningkatan jumlah wisatawan yang kemudian berimplikasi terhadap ketahanan ekonomi wilayah di tingkat Kabupaten Trenggalek, terutama dalam hal pertumbuhan ekonomi dan pemerataan pendapatan. Penelitian Sulistiawati (2013) tentang partisipasi masyarakat dalam pelaksanaan PNPM mandiri perdesaan dan efektivitasnya terhadap ketahanan ekonomi keluarga menunjukkan bahwa program PNPM Mandiri cukup efektif dalam meningkatkan pendapatan kepala keluarga dan belum efektif untuk memenuhi pendapatan keluarga perkapita perhari berdasarkan standar UN, serta belum optimal di semua desa, sehingga mengakibatkan ketahanan ekonomi keluarga yang tidak merata di semua desa. Penelitian Zulkarnain (2015) peran Balai Pemuda dan Olahraga (BPO) Yogyakarta dalam upaya pengembangan kewirausahaan pemuda untuk mendukung ketahanan ekonomi keluarga menunjukkan BPO Provinsi DIY berperan pada aspek pelatihan dan pemagagan, serta belum berperan penuh pada aspek bantuan dan spek permodalan dari 7 indikator yang dinilai. BPO Provinsi DIY berperan mendukung ketahanan ekonomi keluarga bagi masyarakat yang mengembangkan kewirausahaan pada bidang budidaya lele.

Penelitian-penelitian terdahulu memfokuskan pada peran, baik peran pemuda ataupun peran instansi bagi masyarakat. Peneliti belum menemukan penelitian terdahulu membahas suatu kasus dengan teori khusus, sehingga kebaruan penelitian ini adalah mengulas tentang inovasi pemuda dalam mendukung ketahanan ekonomi keluarga di KWJ, Kecamatan Blimbing, Kota Malang dengan menggunakan teori tindakan komunikatif Jurgen Habermas. Bagaimana pemuda mengkomunikasikan ide-idenya di suatu kelompok masyarakat, dan bagaimana inovasi tersebut memberi dampak bagi ketahanan ekonomi keluarga di lingkungan tersebut. Penelitian ini mengambil lokus di RT 6, 7, 9 RW 02 Kelurahan Jodipan, Kecamatan Blimbing, Kota Malang. Penelitian menggunakan pendekatan kualitatif, dengan langkah pengambilan data melalui tiga tahap: observasi, wawancara, dan dokumentasi. Observasi dilakukan peneliti dengan mengunjungi KWJ. Peneliti membandingkan kondisi KWJ sebelum dicat dan sesudah dicat melalui dokumentasi foto yang ada di berita www.bbc.com. Peneliti juga melakukan studi literatur di surat kabar online $w w w$. muhammadiyah.or.id yang membahas tentang peran mahasiswa komunikasi UMM yang tergabung dalam kelompok Guys Pro, surat kabar Surya Malang suryamalang.tribunnews. com, dan www.bbc.com. 
Subjek penelitian ini terdiri dari tiga informan kunci, yakni Ketua RW 02 Kelurahan Jodipan, inisiator KWJ yakni Nabila Fidausyiah (yang menjadi ketua dalam project $\mathrm{KWJ}$ ), serta warga masyarakat yang mendirikan usaha di sekitar KWJ. Objek dalam penelitian ini adalah inovasi yang diciptakan oleh pemuda dan ketahanan ekonomi keluarga di KWJ. Inovasi pemuda akan dibahas dengan menggunakan teori tindakan komunikatif Jurgen Habermas.

Ketahanan ekonomi diartikan sebagai kondisi dinamik kehidupan perekonomian bangsa yang berisi keuletan dan ketangguhan yang mengandung kemampuan pengembangan kekuatan nasional dalam menghadapi segala tantangan, ancaman, hambatan, dan gangguan, baik yang dating dari luar maupun dari dalam, yang langsung maupun tidak langsung untuk menjamin kelangsungan hidup perekonomian bangsa dan Negara Republik Indonesia berdasarkan Pancasila dan Undang-Undang Dasar 1945. Ada beberapa faktor yang mempengaruhi ketahanan ekonomi, antara lain sifat keterbukaan dan sistem perekonomian; manajemen; hubungan ekonomi luar negeri; diversifikasi pemasaran; teknologi; struktur ekonomi; infrastruktur (sarana dan prasarana); potensi dan pengelolaan sumber daya manusia; potensi dan pengelolaan sumber dana (Lemhannas, 1997). Anoraga dan Widiyanti (1993) menjelaskan beberapa unsur yang dapat digunakan untuk melihat ketahanan ekonomi secara nasional, yaitu pertumbuhan ekonomi nasional, pemerataan pendapatan, dan stabilitas ekonomi nasional.

Mengerucut ke skala yang lebih kecil, yakni ketahanan ekonomi wilayah merupakan wujud ketahanan ekonomi nasional di wilayah (provinsi, kota/kabupaten) yang mencerminkan kondisi kehidupan yang berdasarkan Pancasila, yang mengandung kemampuan memelihara stabilitas ekonomi yang sehat dan dinamis serta kemampuan menciptakan kemandirian ekonomi di suatu wilayah yang berdaya saing tinggi dan mewujudkan kemakmuran rakyat yang adil dan merata. Unsur yang digunakan untuk melihat ketahanan ekonomi wilayah yaitu pertumbuhan ekonomi dan pemerataan pendapatan (Ibrahim, 2006). Mengacu dari pengertian tersebut, ketahanan ekonomi keluarga merupakan kondisi dinamik suatu keluarga yang berisi keuletan dan ketangguhan yang mengandung kemampuan mengembangkan kekuatan keluarga dalam menghadapi dan mengatasi segala tantangan, ancaman, dan hambatan serta gangguan baik yang dating dari luar maupun dari dalam, yang langsung maupun tidak langsung membahayakan kelangsungan kehidupan ekonomi keluarga. Keluarga merupakan unit terkecil dari sebuah negara, sehingga apabila keluarga memiliki ketahanan ekonomi yang tangguh maka negara memiliki fondasi ekonomi yang kuat.

Ketahanan ekonomi keluarga diukur menggunakan parameter penghasilan atau pengeluaran per rumah tangga dalam jangka waktu tertentu dibandingkan dengan batas kemiskinan. Menurut World Bank (2006) kemiskinan dapat dibagi menjadi dua kategori yakni kategori sangat miskin yang dapat dilihat dari indikator pendapatan perkapita per hari sebesar kurang dari US \$1. Kategori miskin dlihat dari indikator pendapatan perkapita perhari antara US \$1 hingga US \$2, sedangkan kategori tidak miskin dilihat dari indikator pendapatan perkapita per hari sebesar lebih dari US \$2 (Zulkarnain, 2015).

Lebih lanjut Zulkarnain (2015) menjelaskan seseorang dapat dikategorikan miskin jika diukur dari pendapatan yang 


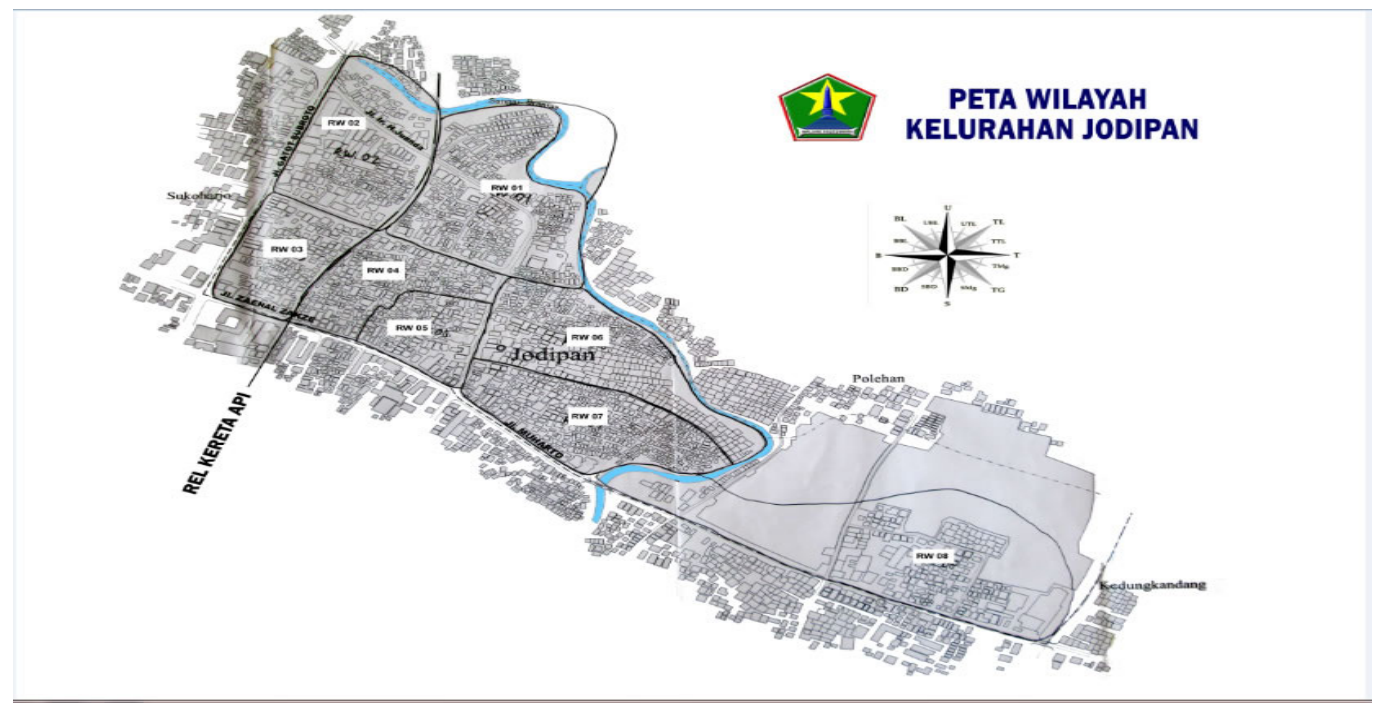

Sumber: keljodipan.malangkota.go.id (diunduh 10 September 2017)

diperoleh kurang atau masih di bawah standar dari UMK yang ditetapkan oleh pemerintah setempat, sedangkan kategori tidak miskin jika pendapatan lebih dari UMK yang sudah ditetapkan. Sebagaimana yang dijelaskan dalam Peraturan Gubernur No 121 Tahun 2016 tentang UMK di Jawa Timur tahun 2017, untuk Kota Malang sebesar 2.272.160,50. Indikator ketahanan ekonomi keluarga masyarakat KWJ juga akan dilihat berdasarkan UMK, apakah pendapatan masyarakat di atas UMK atau di bawah UMK.

\section{PEMBAHASAN}

\section{Profil Kampung Warna-Warni Jodipan}

Kota Malang merupakan salah satu kota di Jawa Timur yang memiliki kawasan permukiman sebagai salah satu permasalahan di kawasan perkotaan. Permukiman kumuh merupakan permasalahan klasik yang sejak lama telah berkembang di kotakota besar. Permukiman kumuh memiliki tingkat kepadatan penduduk dan bangunan yang lebih tinggi daripada kampung biasa dan berlokasi di sepanjang aliran Sungai Brantas, sekitar rel kereta api, dan juga pada beberapa kawasan kampung lainnya. Permukiman kawasan kumuh di Kelurahan Jodipan termasuk dalam kategori kumuh sedang, dengan permasalahan utama kawasan kumuh adalah kondisi fisik hunian, sanitasi, drainase, kepadatan penduduk, kepadatan bangunan (PU Kota Malang, 2014). Penelitian ini memfokuskan pada RW 2 di Kelurahan Jodipan, yang saat ini menjadi kawasan wisata Kampung WarnaWarni Jodipan. Gambar 1 di atas adalah peta lokasi Kelurahan Jodipan, Kecamatan Blimbing Kota Malang

Dalam peta Kelurahan Jodipan, terlihat dengan jelas bahwa wilayah tersebut sangat padat dengan pemukiman penduduk. Permukiman di Kelurahan Jodipan berbatasan langsung dengan Sungai Brantas. Situasi tersebut membuat kebiasaan buruk masyarakat untuk membuang sampah di sungai. Sampah rumah tangga yang menumpuk di sungai membuat aliran sungai tidak lancar, bau 


\section{Gambar 2}

RW 2 Kelurahan Jodipan Sebelum Dan Sesudah Menjadi KWJ

(Dari Jembatan Sungai Brantas)
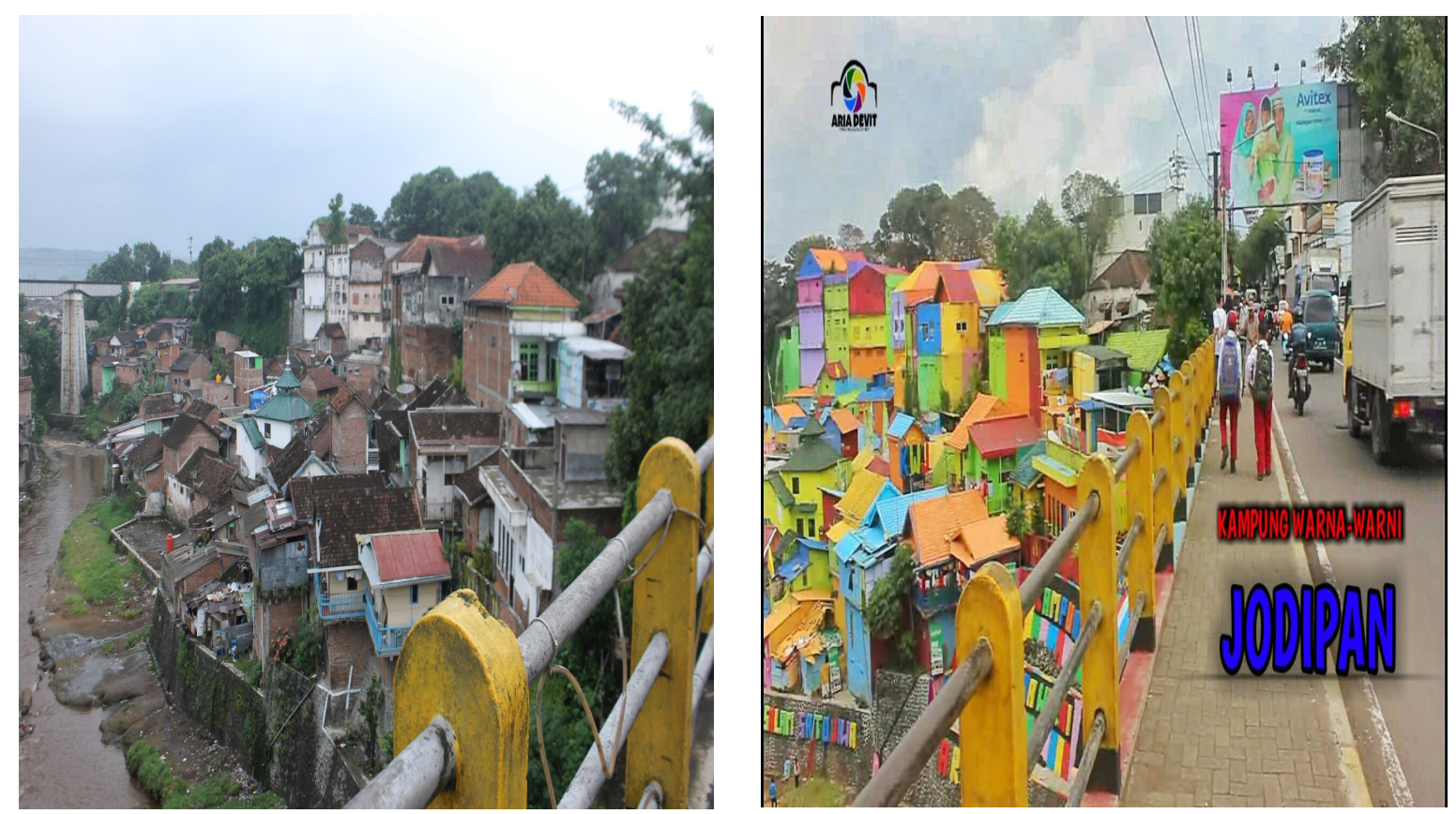

Sumber: www.bbc.com, diunduh 10 September 2017

tidak sedap, serta pemandangan yang tidak indah. Sebagian besar keluarga yang tinggal di Jodipan tidak memiliki sanitasi. Beberapa surat kabar baik memberitakan, kondisi yang kumuh mendorong pemerintah Kota Malang merelokasi warga untuk dipindahkan ke rumah susun. Di samping itu tanah yang digunakan oleh warga untuk membangun rumah masih merupakan tanah negara (www.bbc.com diunduh 10 September 2017).

Kampung Warna Warni Jodipan merupakan sebutan untuk wilayah yang terletak di RT 6, RT 7, dan RT 9 di RW 2 Kelurahan Jodipan, Kecamatan Blimbing, Kota Malang. Pada awalnya kawasan tersebut nampak kumuh jika dilihat dari atas jembatan Sungai Brantas (keljodipan.malangkota. go.id). Gambar 2 di atas adalah kondisi RW 2 Kelurahan Jodipan, sebelum dan sesudah menjadi KWJ.

\section{Profil Guys Pro}

Pendidikan merupakan salah satu upaya memberdayakan generasi muda mencapai kesejahteraan. Pada abad ke-20 wilayah Hindia-Belanda mengalami kenaikan permintaan tenaga kerja terdidik untuk bekerja pada pemerintah kolonial. Salah satu dampaknya diimplementasikannya politik etis guna menyediakan pendidikan bagi kaum pribumi. Banyak dibuka sekolah-sekolah Belanda pada saat itu. Akan tetapi, kaum pribumi yang dapat bersekolah dibedakan, kaum elit pribumi dan rakyat kecil. Pendidikan barat yang berkembang pada masa politik etis memberikan hasil signifikan terhadap perjuangan kemerdekaan Indonesia. Setelah beberapa tahun politik etis berlangsung, beberapa kelompok elit pribumi sadar bahwa kondisi bangsa pribumi sedang dijajah. Mereka berinovasi untuk melepaskan penjajahan, 
salah satunya dengan menyebarluaskan ilmu yang diperoleh dari sekolah Belanda. Pada saat itu ilmu yang disebarluaskan juga masih terbatas, yakni baca, tulis, dan hitung (calistung). Kaum elit pribumi yang kontra terhadap pemerintah kolonial mulai mencoba melawan penjajahan secara lunak, yakni dengan mendirikan organisasi, salah satunya Budi Utomo di tahun 1908. Tujuan organisasi tersebut masih sekedar memberikan pendidikan kepada rakyat. Baru kemudian berdiri organisasi radikal Indische Partij di tahun 1912 oleh Tiga Serangkai. Meskipun partai tersebut ditolak oleh pemerintah kolonial, para pendirinya melawan pemerintah kolonial dengan menyebarkan berbagai tulisan propaganda anti penjajahan yang diterbitkan di surat kabar. Hal tersebut membuat pendiri Indische Partij diasingkan di negeri Belanda (Dhont, 2005).

Seiring berjalannya waktu, perjuangan kemerdekaan akibat pengaruh pendidikan yang semakin luas dipenuhi oleh para kaum muda, seperti Soekarno, Moh. Hatta, Sutan Syahrir, dan lain-lain. Pasca kemerdekaan pun salah satu amanat UUD 1945 adalah mencerdaskan kehidupan bangsa, sehingga terimplementasi dalam Wajib Belajar 12 tahun. Pemuda yang sadar akan pendidikan memiliki dampak signifikan terhadap kemajuan zaman. Apabila berkaca dari masa lalu, pada masa kediktatoran Soekarno dan Soeharto yang berhasil menggulingkan kedua rezim tersebut adalah generasi muda yang kritis yakni mahasiswa. Protes-protes keras ketidakadilan di negeri ini juga sangat gentar disuarakan oleh pemuda (mahasiswa). Apabila ditelaah lebih jauh pemuda menjadi agen perubahan suatu zaman. Pemuda memiliki berbagai inovasi untuk melawan ketidak-adilan dan upaya untuk memajukan kelangsungan bangsa dan negara di masa depan. Ide-ide kreatif pemuda diharapkan mampu melahirkan karya-karya besar yang bermanfaat bagi lingkungan sekitar (Wulandari dkk, 2017).

Institusi pendidikan terutama Perguruan Tinggi baik PTN atau PTS berlomba-lomba menghasilkan outcome yang berkualitas. Salah satunya yakni Universitas Muhammadiyah Malang (UMM) mendukung pendidikan berkemajuan. Outcome PTN/PTS diharapkan mampu memberikan kontribusi bagi dirinya dan masyarakatnya. Program Studi (prodi) Ilmu Komunikasi UMM merupakan salah satu prodi andalan UMM. Animo positif dari masyarakat terlihat dari semakin meningkatnya peminat di prodi tersebut. Materi kurikulum terus-menerus disesuaikan dengan perkembangan zaman, serta mempunyai cirri khas bahwa prodi tersebut mengusung gerakan "Literasi Media" dalam aktualisasinya. Setiap proses belajar mengajar dan kegiatan akademis berada dalam payung "Literasi Media" tersebut. Prodi ini memiliki beberapa peminat kajian, yaitu Komunitas mahasiswa peminat kajian Public Relation (PR Club dan Eskalator); peminat kajian jurnalistik (Journalistic Club); peminat kajian Audio Visual (AV Club); peminat kajian Riset Komunikasi (Kociris). Prodi ini memotivasi mahasiswa untuk berkarya dalam sejumlah praktikum. Sejauh ini, karya yang dihasilkan tidak hanya bermanfaat bagi mahasiswa secara keilmuan, tetapi juga bermanfaat bagi pemerintah dan masyarakat. Salah satu karya besar mahasiswa Ilmu Komunikasi yang menjadi buah bibir masyarakat saat ini adalah "Kampung Warna-Warni Jodipan" yang digarap oleh peminat kajian Public Relation dengan nama kelompok Guys of Public Relation (Guys Pro) (http://komunikasi.umm.ac.id/).

Guys Pro adalah salah satu kelompok Public Relation (PR) Ilmu komunikasi 
Universitas Muhammadiyah Malang (UMM). Guys Pro telah berhasil merubah pemukiman Jodipan yang semula tampak kumuh menjadi kawasan indah nan elegan. Kelompok Guys Pro terdiri dari delapan orang, yang terdiri dari Nabila Firdausiyah, Salis Fitria, Ira Yulia Astutik, Dinni Anggraeni, Wahyu Fitria, Elmy Nuraidah, Fahd Afdallah, dan Ahmad Wiratman. Project kawasan Jodipan berawal dari sebuah tugas PR yang mewajibkan mahasiswa memberikan kontribusi kepada masyarakat. Tugas tersebut memancing kreativitas mahasiswa, Guys Pro mempunyai ide untuk merubah image kumuh kawasan Jodipan. Project diawali dengan melakukan observasi di kawasan kumuh Jodipan. Salah seorang anggota Guys Pro selama obsevasi menceritakan:

"Kami juga menemukan fakta bahwa masyarakat Jodipan lebih senang membuang sampash di sungai, karena tinggal melempar saja. Selain itu tempat pembuangan akhir memang terlalu jauh dari pemukiman warga" (Nabila Firdausy dalam Berita Pimpinan Pusat Muhammadiyah, 2016).

Kondisi geografi di kawasan Jodipan yang mendukung, yakni lahan yang miring, letak rumah di bawah jembatan sehingga kelihatan dari jalan besar, dan jarak antara satu rumah dengan rumah yang lain sangat padat menginspirasi para Guys Pro untuk menciptakan kawasan Kickstater Rio De Janeiro ala Indonesia.

Hatta dalam Wulandari dkk (2017) memiliki gagasan bahwa hanya pemuda yang sanggup mengubah tatanan sosial yang membungkus ketidakadilan, karena pemuda masih murni jiwanya dan ingin melihat pelaksanaan kebijakan pemerintah secara jujur seperti yang telah dijanjikan pada rakyat; dan pemuda dalam status mahasiswa pada universitas dididik untuk berpikir secara ilmiah. Sama hal nya yang dilakukan oleh Guys Pro, ketika melihat suatu permasalahan di lapangan, kemudian pemerintah yang menjanjikan keadilan terhadap rakyatnya tidak juga menepati janjinya. Guys Pro merupakan kelompok pemuda terdidik mencoba membuat sebuah perubahan guna mengentaskan masyarakat dari permasalahan sosial yang sudah lama dialaminya sejak lama. Bedanya jika mahasiswa pada masa orde lama dan orde baru menagih janji pemerintah yang tak kunjung direalisasikan, Guys Pro berinovasi untuk membantu menyelesaikan permasalahan pemerintah, tanpa merugikan kedua belah pihak, yakni masyarakat dan pemerintah.

\section{Inovasi Pemuda Merubah Image Kawasan Kumuh Jodipan: Analisis Teori Tindakan Komunikatif Jurgen Habermas}

Tindakan komunikasi Habermas, secara garis besar adalah sebagai berikut: (1) Masyarakat akan berkembang bukan ke arah kekuasaan tetapi ke arah komunikasi rasionalitas bukan lagi teknis dan instrumental tapi ke arah komunikasi. Rasionalitas mendorong manusia melakukan tindakan komunikatif satu sama lain sehingga tercipta pengertian antar individu di masyarakat; (2) Berkomunikasi bukan dengan teror dan kekerasan, tetapi perlu akal budi dan tindakan untuk mencapai saling pengertian. Melalui etika diskursus masyarakat dengan pluralitas dan pandangan dasar dapat hidup bersama secara damai; (3) Tindakan komunikasi mengarah pada suatu pencapaian yang lebih tinggi, lebih luhur, lebih bebas, dan lebih bernilai. Dalam arti tindakan komunikatif bersifat emansipatoris berorientasi menyelamatkan; (4) Agama berada dalam 
situasi sulit untuk beresonansi secara kognitif terhadap pluralisme yang terjadi akibat modernisme. Akal budi komunikatif tidak akan eksklusif terhadap agama tetapi akan berkoeksistensi dengan agama, berdampingan dengan agama, dan terus kritis dengan agama. Komunikasi tidak boleh mengecilkan siapapun, semua unsur masyarakat harus bersama menuju masyarakat yang komunikatif untuk meraih kehidupan yang lebih baik dari sekarang (Sri Sumartini dalam Suyanto \& Amal, 2010).

Lebih lanjut Habermas menjelaskan kelanjutan teorinya, yang disebut dengan teori kompetensi komunikatif yang dinilai banyak orang lebih analitis. Pembahasan sebelumnya, sasaran kritik ideologi teori kritis adalah komunikasi yang terdistorsi secara sistematis. Oleh karena itu, harus diusahakan suatu perangkat teori komunikasi tersebut dengan menggunakan analisis bahasa karena berkomunikasi itu menggunakan bahasa. Teori Kompetensi Komunikatif merupakan sarana untuk merekonstruksi prasyarat-prasyarat umum bagi komunikasi bebas penguasaan. Dalam hal ini Habermas memakai teori speech acts (tindakan tutur). Habermas menganalisis sifat khusus praksis komunikatif dengan memanfaatkan teori yang berasal dari John Austin dan John Searle. Inti teori ini bahwa berbahasa atau berbicara harus dimengerti sebagai sedang melakukan perbuatan-perbuatan tertentu (Irfaan, 2009).

Tinjauan Kompetensi Komunikatif menjadikan proses komunikasi yang bebas dari penguasaan, dalam arti terdapat adanya suatu komunikasi yang genuine. Maksudnya, suatu komunikasi yang tidak terdistorsi secara ideologis dan untuk menghasilkan komunikasi yang genuine dan bebas distorsi idelogis memerlukan prasyarat khusus. Prasyarat khusus tersebut menurut Habermas, yakni kondisi masyarakat harus berada dalam situasi "perbincangan ideal" terlebih dahulu, yang dijelaskan Habermas sebagai sebuah struktur komunikasi yang bebas hambatan dengan adanya semua partisipan berkomunikasi dalam menanggapi suatu diskursus dalam ruang publik. Masyarakat diberi kebebasan dan kesempatan yang sama untuk melibatkan diri dalam perbincangan dan mengemukakan penolakan, keterangan, serta penafsiran. Namun demikian, mereka juga dituntut harus lapang dada jika ada keputusan yang tidak menggunakan argumentasi pendapat yang mereka usulkan. Dalam komunikasi yang dialogal, untuk mencapai kebenaran yang dapat diterima, adalah pendapat yang lebih rasional dan lebih baik, bukan pendapat dari pihak yang paling berkuasa, sehingga, proses dialog mengarah pada suatu kebenaran sebagai suatu konsensus. Dalam konteks inilah, Habermas di dalam teori kompetensi komunikatifnya menganut suatu teori the consensus theory of truth, kebenaran diperoleh lewat konsensuskonsensus rasional yang didapatkan oleh subjek-subjek yang berkompeten (Irfaan, 2009).

Tindakan komunikatif dalam suatu masyarakat yang diharapkan oleh Habermas merupakan tindakan komunikatif dua arah, yang saling memberikan pendapatnya sehingga tercipta komunikasi yang seimbang. Komunikasi dilakukan secara terbuka dan intim, tidak berdasarkan tekanan salah satu pihak yang berkuasa ataupun teror. Komunikasi yang demikian diharapkan mampu memberikan solusi terhadap permasalahan yang dihadapi. Sejalan dengan teori Habermas, Guys Pro melakukan komunikasi dengan berbagai pihak sebelum menerapkan ide yang ingin direalisasikan. 
Pemuda yang tergabung dalam Guys Pro memiliki ide untuk mengubah kawasan kumuh Jodipan seperti kawasan Kicstater yang ada di Rio De Janeiro. Langkah awal yang dilakukan oleh Guys Pro adalah menghubugi tokoh masyarakat yang ada di kawasan kumuh Jodipan, yakni Ketua RW 02 Bapak Soni Parin. Hal tersebut sesuai dengan yang disampaikan oleh informan kepada peneliti.

\begin{abstract}
"Suatu hari ada mahasiswa yang datang ke rumah, ia menawarkan idenya ingin merubah Jodipan menjadi kampung warnawarni. Salah satu kelompok menceritakan kepada saya, Kelurahan Jodipan yang terletak di pinggir sungan, posisi rumah yang tidak rata, perkampungan yang lebih rendah dari jalan besar, serta berada di bawah jembatan sangat potensial jika dijadikan sebagai kampong warna-warni. Pada awalnya saya juga tidak begitu paham dengan maksudnya. Akan tetapi, kemudian kelompok Guys Pro menjelaskan secara gamblang kepada saya. Saya tidak berana langsung mengambil keputusan, makanya saya ngomong ke mahasiswa tersebut, saya harus menyosialisasikan dulu kepada masyarakat." (Wawancara dengan Bapak Soni Parin, Minggu 2 Juli 2017).
\end{abstract}

Ketua RW 02 Kelurahan Jodipan kemudian mesosialisasikan gagasan tersebut kepada warga, tetapi ternyata warga belum juga mengerti maksud ide dari Guys Pro. Kemudian Guys Pro dengan ijin Ketua RW melakukan semacam presentasi di kawasan Jodipan dengan menunjukkan contoh gambar. Respon warga sangat positif, warga setuju dengan usulan tersebut.

Apabila ditelaah lebih jauh, masyarakat yang tinggal di kawasan kumuh Jodipan memiliki kebiasaan buruk membuang sampah di sungai, karena tempat tinggalnya dekat dengan sungai. Letak tempat pembuangan sampah akhir yang jauh dari hunian mereka juga mempengaruhi berlangsungnya kebiasaan buruk tersebut. Sungai yang dipenuhi aliran airnya menjadi tidak lancar, sehingga banyak sampah yang mengapung di atas sungai. Pemandangan tersebut sangat tidak indah jika dilihat dari kejauhan, dalam konteks ini dilihat dari atas jembatan.

Guys Pro berinisiatif untuk memutus rantai kebiasaan buruk tersebut. Lokasi yang mendukung memunculkan ide Guys Pro untuk menciptakan kampung warna-warni di Kelurahan Jodipan. Guys Pro berharap ketika kawasan Jodipan menjadi salah satu obyek wisata kota dan dapat memberikan pemasukan bagi warga sekitar. Ketika suatu tempat menjadi kawasan wisata dan didatangi banyak pengunjung maka masyarakat akan merubah kebiasaan buruk untuk tidak membuang sampah di sungai. Kunjungan wisatawan mendorong masyarakat sekitar untuk kreatif menyediakan barang dan jasa yang dibutuhkan oleh pengunjung.

Pada saat peneliti melakukan observasi di KWJ, keadaan Kelurahan Jodipan memang berbeda dengan dengan sebelum dicat. Peneliti membandingkan foto kawasan Jodipan sebelum dicat dengan sesudah dicat sangat berlainan. Saat ini KWJ sangat bersih. Masyarakat sudah tidak membuang sampah di sungai. Setiap pagi ada petugas kebersihan yang mengambil sampah di tiap-tiap rumah, sehingga memerlukan biaya imbalan uang kebersihan. Pemasukan dari penjualan tiket masuk sebagian disisihkan untuk membayar uang kebersihan. Berikut informasi yang disampaikan oleh Ketua RW 02.

\footnotetext{
"Setiap pagi sampah-sampah disini ada yang ngambil. Kalau dulu kan warga terbiasa buang ke sungai, karena dekat, dan berada tepat di belakang rumahnya, sekarang sudah tidak. Adanya petugas
} 
kebersihan, jadi harus menyisihkan uang untuk membayar uang kebersihan, dan itu diambilkan dari penjualan tiket masuk. (Wawancara dengan Bapak Soni Parin 2 Juli 2017)”

Kebiasaan buruk warga berhasil dihilangkan dengan adanya tatanan baru di masyarakat, yaitu kawasan kampung yang dijadikan lokasi wisata. Kedatangan pengunjung yang memberikan keuntungan bagi masyarakat, memotivasi masyarakat untuk menjaga kenyamanan pengunjung yang datang. Para wisatawan akan merasa nyaman jika melihat kawasan wisata itu bersih.

Manusia adalah pencipta kenyataan sosial yang objektif melalui proses eksternalisasi, sebagaimana kenyataan objektifmempengaruhi kembali manusia melalui proses internalisasi yang mencerminkan kenyataan subjektif. Dengan kemampuan berpikir dialektis, dimana terdapat tesis, antitesis, dan sistesis, Berger memandang masyarakat sebagai produk manusia dan manusia menjadi produk masyarakat (Sriningsih dalam Suyanto \& Amal, 2010). Berdasarkan penjelasan tersebut, peneliti memahami bahwa realitas sosial selalu mengalami dialektika. Eksternalisasi merupakan tatanan sosial yang dihasilkan oleh salah seorang individu atau kelompok. Objektivasi merupakan sikap menerima tatanan sosial baru yang diusulkan oleh individu atau kelompok dan disepkati menjadi tatanan sosial bersama dalam kehidupan bermasyarakat. Dialektika antara eksternalisasi dan objektivasi dijembatani oleh tindakan komunikasi.

Berdasarkan penjelasan di atas, peneliti menyimpulkan bahwa agar tercapai suatu masyarakat yang harmoni, apabila ditemui perbedaan maka perlu dikomunikasikan. Tindakan komunikasi yang dilakukan antar individu dalam masyarakat atau antar kelompok dalam masyarakat merupakan komunikasi yang inklusif. Komunikasi harus didasari oleh akal budi. Komunikasi harus dilakukan oleh siapapun, tidak boleh sedikitpun anggota masyarakat terlewatkan. Di samping itu, mufakat atau hasil kesepakatan dari tindakan komunikasi harus bertujuan mencapai suatu tatanan yang lebih tinggi, luhur, bebas, dan lebih bernilai.

Lebih lanjut digambarkan, pemikiran Guys Pro untuk menciptakan tatanan baru di kawasan Jodipan diterima oleh warga. Hal tersebut menunjukkan, bahwa ide-ide yang diusulkan oleh Guys Pro menjadi pedoman objektif bagi warga Jodipan. Sebelum itu, sesuai dengan teori Habermas yang telah dijelaskan, kelompok Guys Pro melakukan tindakan komunikasi dengan masyarakat di kawasan Jodipan. Pertama-tama kelompok Guys Pro mendatangi tokoh lokal setempat, yakni Ketua RW 02. Berawal dari Ketua RW, Guys Pro mesosialisasikan secara langsung project-nya kepada warga. Komunikasi yang dilakukan adalah komunikasi yang terbuka, bukan komunikasi yang penuh tekanan dan intimidasi. Hal tersebut dapat digambarkan dengan hasil wawancara sebagai berikut.

“...Pada awalnya saya dan warga juga tidak tahu kampung warna-warni itu seperti apa. Nanti kampung kami akan jadi bagaimana. Pertanyaaan-pertanyaan yang timbul dari benak kami sebagai warga, kami tanyakan kepada kelompok Guys Pro. Kemudian mereka memberikan penjelasan maksud dari projectnya." (Wawancara dengan Ketua RW 02, Minggu, 2 Juli 2017).

Berdasarkan hasil wawancara tersebut terlihat adanya kesetaraan dalam komunikasi. Antara mahasiswa (Guys Pro) yang memiliki pendidikan lebih tinggi, dan pengetahuan 
lebih luas dari pada warga kawasan Jodipan tidak memposisikan dirinya lebih tinggi atau yang lebih tahu segalanya. Kelompok Guys Pro bersedia menjelaskan pertanyaanpertanyaan warga, sehingga warga memahami maksud dari projectnya. Komunikasi baik yang dijalin oleh kelompok Guys Pro dan masyarakat memberikan respon positif, masyarakat bersedia rumahnya dicat warnawarni. Warga menyambut dengan senang hati rumahnya diperindah dengan cat warnawarni. Sikap penerimaan warga ditunjukkan, dengan menyediakan makanan dan jajanan untuk para tukang cat yang sedang mengecat rumahnya. Dalam hal ini warga memberikan dukungan terhadap project Guys Pro. Berikut disampaikan oleh Bapak Soni Parin:

“...setelah kami mengetahui maksud dari mahasiswa, kami setuju rumah kami dicat..." (Wawancara dengan Bapak Soni Parin pada 2 Juli 2017)

Komunikasi yang baik antara Guys Pro dan warga terlihat ketika, pihak Guys Pro menawarkan kepada setiap warga rumahnya mau dicat warna apa dan mau digambar dengan gambar apa. Komunikasi yang dilakukan tidak sepihak, tetapi kedua belah pihak saling melakukan komunikasi.

Suatu tatanan baru agar dikenal, diakui, dan diimplementasikan oleh masyarakat maka harus disosialisasikan. Obyek wisata baru perlu dilakukan promosi secara terus-menerus agar dikenal oleh masyarakat. Saat ini trend promosi pariwisata dilakukan dengan media sosial. Hal tersebut menekan biaya promosi, dan hasilnya secara langsung bisa dinikmati. Gaya komunikasi generasi milenial saat ini berbeda, pemuda lebih aktif menggunakan tekhnologinya dalam berkomunikasi. Berbagai media sosial memfasilitasi pemuda dalam berkomunikasi, sama halnya dengan Tim Guys Pro aktif memperkenalkan KWJ di media sosial. Sejauh ini peneliti menemukan terdapat banyak media sosial yang digunakan sebagai sarana promosi, yaitu instagram, facebook, dan line.

Tim Guys Pro berusaha menarik minat calon pengunjung agar penasaran dan kemudian mengunjungi KWJ. Mereka mengunggah foto-foto menarik di media sosial. Mereka juga menonjolkan spot-spot yang menarik digunakan untuk ber-selfie. Generasi milenial saat ini memang cenderung menunjukkan eksistensinya melalui foto di spot-spot yang kekinian. Trend tersebut menjadi strategi bagi tim Guys Pro menarik minat pengunjung. Pertanyaan-pertanyaan yang disampaikan oleh pengguna media sosial kepada tim Guys Pro dijawab dengan ramah dan jelas. Jawaban terhadap pertanyaan pengguna media sosial, juga mempersuasi untuk datang ke KWJ. Sesuai dengan gagasan Habermas, bahwa komunisi mengarah pada tindakan yang lebih bernilai. Kondisi yang sama juga dilakukan oleh Guys Pro, keramahannya dalam menarik minat pengunjung, semakin meningkatkan wisatawan yang datang. Kunjungan wisatawan memberikan dampak positif pada perekonomian masyarakat sekitar.

Komunikasi intim yang terjalin antara Guys Pro dengan warga msyarakat memotivasi masyarakat untuk berinovasi terhadap daerahnya sendiri. Warga masyarakat menerima tempat huniannya di cat dengan aneka warna dengan tujuan dijadikan sebagai daerah tujuan wisata (DTW), ikut ambil bagian dengan menyediakan barang-barang kebutuhan yang diperlukan oleh wisatawan (lihat gambar 3).

Sebelum KWJ menjadi kawasan wisata, di sana adalah perkampungan kumuh dengan 
Prisca Kiki Wulandari -- Inovasi Pemuda Dalam Mendukung Ketahanan Ekonomi Keluarga (Studi Di Kampung Warna-Warni Kelurahan Jodipan, Kecamatan Blimbing, Kota Malang)

Gambar 3

Aktivitas Warga (Kiri) accessories khas Kampung Warna-Warni Jodipan (Kanan)

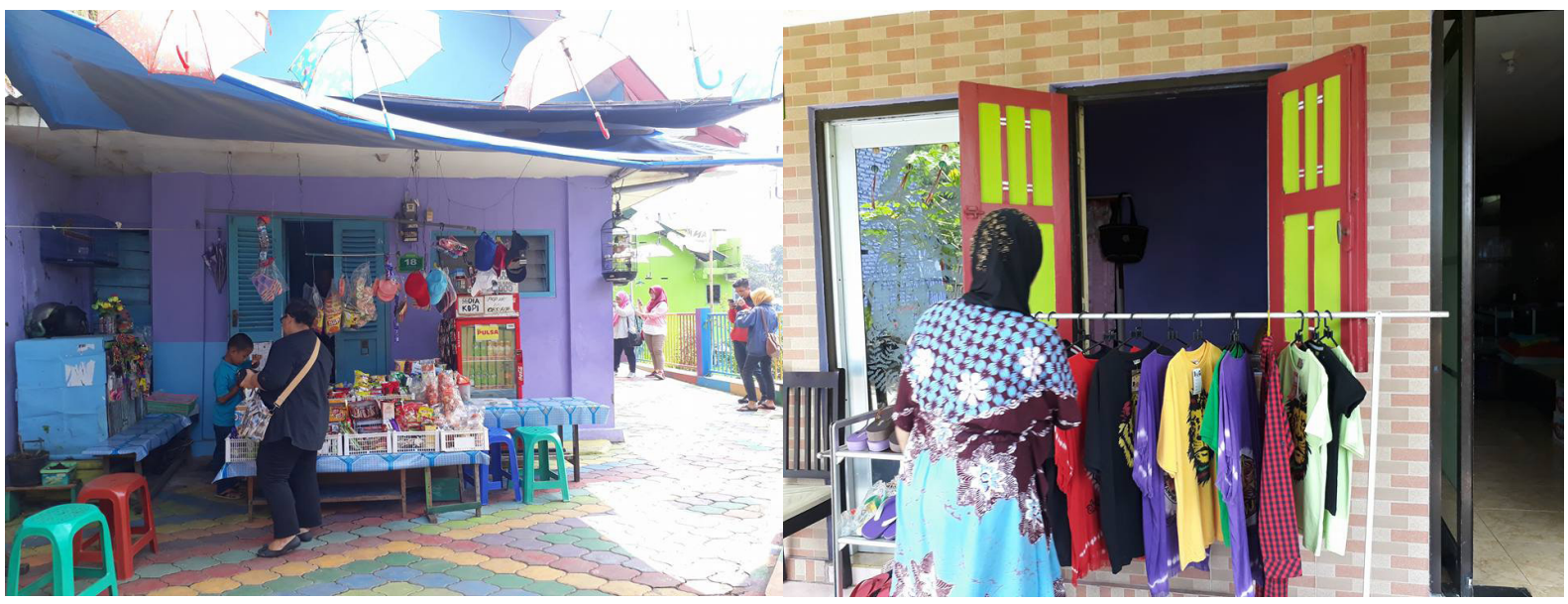

Sumber : Dokumentasi Peneliti, 18 April 2017

warga yang tidak kreatif. Akan tetapi setelah dibuka menjadi DTW, masyarakat menjadi kreatif. Sebagian besar masyarakat, secara individu membuka usaha di rumahnya sendiri. Masyarakat menganggap bahwa lingkungannya sangat potensial dimanfaatkan untuk aktivitas ekonomi. Informasi serupa juga disampaikan oleh Ketua RW 02.

“..Dulu sebelum menjadi KWJya sedikit yang jualan. Tetapi sekarang banyak orang yang datang, masyarakat jadi kreatif sendiri. Mereka sadar bahwa banyak orang yang datang dapat memberikan keuntungan ekonomi. Dampak positifnya perekonomian masyarakat di sini jadi terangkat.." (wawancara dengan Pak Parin pada hari Minggu, 2 Juli 2017)

Berdasarkan pengamatan peneliti, manajemen organisasi di KWJ sudah tertata dengan baik. Sikap Ketua RW yang tegas dan bijaksana mampu mewadahi masyarakat. Dibukanya KWJ sebagai DTW tidak hanya menguntungkan secara individu tetapi juga menguntungkan kelompok masyarakat yang ada di KWJ. Saat ini di KWJ terdapat beberapa lapangan pekerjaan tambahan yang menjadi peluang bagi warga setempat. Ketua pengurus KWJ, yakni Ketua RT 7, membagi-bagi warganya dalam beberapa kelompok. Ada yang bertugas menjaga lahan parkir, ada yang bertugas menjaga tiket masuk, ada yang bertugas bagian pemasaran, dan ibu-ibu PKK di KWJ kreatif dalam menghias KWJ dengan accesoris yang menarik peminat wisatawan untuk mengabadikan fotonya.

\section{Inovasi Pemuda Mendukung Kreativitas Warga Setempat}

Semenjak Jodipan menjadi kampung wisata, masyarakat yang tinggal di sekitar Jodipan memanfaatkan kesempatan tersebut. Selain menyediakan makanan ringan, minuman, dan accessories untuk para pengunjung, warga yang tergabung menjadi anggota ibu-ibu PKK aktif mendekorasi ornamen yang ada di sekitar KWJ. Setiap dua bulan sekali ornamen diganti dengan yang baru. Para pemuda setempat juga mural ulang dengan gambar baru setiap dua bulan sekali. Hal tersebut merupakan salah satu strategi untuk menarik minat pengunjung, supaya pengunjung tidak bosan jika datang 
Gambar 4

Ornamen Dan Mural Kreativitas Warga
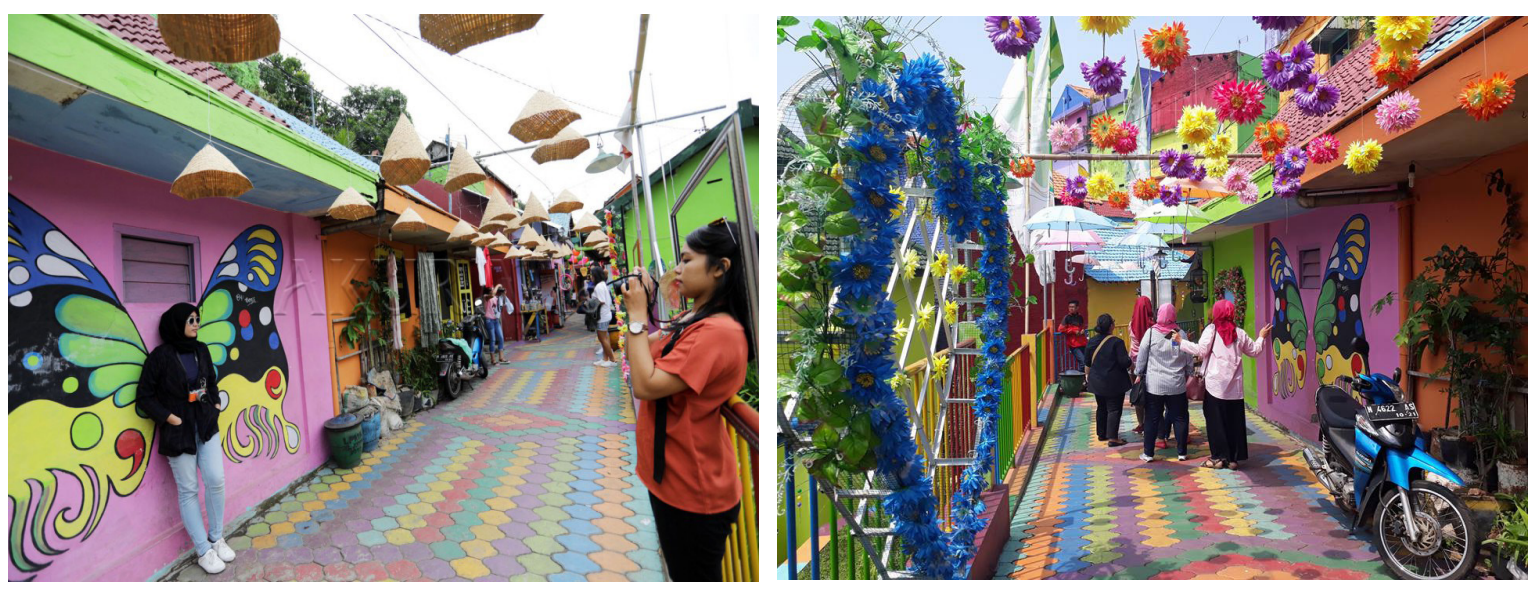

Sumber: Dokumentasi Peneliti, 18 April 2017

berkali-kali ke sana dan selalu ada sesuatu yang baru.

Beberapa tahun terakhir ini, anak-anak muda menggandrungi dengan kegiatan baru yang bernama selfie. Selfie berasal dari kata self yang diartikan sebagai diri. Selfie merupakan sinonim dari kata narsis. Selfie merupakan tindakan mengabadikan mengabadikan diri pada sebuah momen yang dianggap penting oleh individu yang bersangkutan. Dalam perkembangan saat ini, selfie menjadi gaya hidup baru bagi masyarakat, bahkan tanpa mengenal usia, baik tua atau muda semua melakukan tindakan ini (Raditya, 2014). Kegemaran baru masyarakat modern saat ini merupakan peluang bagi masyarakat KWJ. Masyarakat mempunyai motivasi untuk selalu kreatif menciptakan hal-hal baru di KWJ. Orang-orang yang gemar ber-selfie selalu mencari sesuatu yang baru untuk diabadikan, terutama di tempat wisata.

Lebih lanjut Raditya (2014) menjelaskan bahwa hasil selfie tidak dinikmati secara pribadi tetapi diposting atau diunggah di media sosial. Dunia maya sangat signifikan dalam perkembangannya, kini dapat dijumpai media sosial yang menyediakan dan memamerkan posting selfie pribadi ke ranah publik. Tanpa filter, semua foto dapat diunggah ke media sosial, dan dapat dinikmati oleh orang banyak. Secara implisit, hal tersebut mengandung pesan bahwa media sosial menjadi arena eksistensi mereka untuk memposting foto selfie dengan momen terbaik yang mereka punya. Semakin sebuah moment mengandung nilai yang prestisius, maka individu yang memposting foto selfie tersebut semakin eksis. Fenomena merupakan sebuah peluang untuk memperkenalkan KWJ secara tidak langsung. Semakin menarik ornamen atau mural kreativitas yang dihasilkan oleh warga, maka semakin banyak pengunjung yang berselfie, dan secara tidak langsung pengunjung yang memposting fotonya berkunjung ke KWJ di media sosial sudah pasti sekaligus memperkenalkan KWJ ke khalayak umum (lihat gambar 4).

Gambar 4 tersebut memperlihatkan bagaimana kreativitas warga. Kedua gambar berada di tempat yang sama, tetapi diambil dalam waktu yang berbeda. Ornamen di gambar sebelah kiri dibuat sebelum gambar 
di sebelah kanan. Gambar 4 di sisi kiri belum ada hiasan bunga berbentuk love. Beberapa bulan kemudian, ornamen diperbarui di gambar 4 sebelah kanan. Anyaman bambu yang berbentuk kerucut diganti dengan payung dan hiasan bunga dengan posisi yang sama yakni digantung.

Ornamen-ornamen yang semakin kreatif digemari oleh pengunjung untuk berselfie (mengabadikan fotonya) kemudian diunggah di media sosial. Unggahan-unggahan foto pengunjung di media sosial ketika datang ke KWJ sekaligus mempromosikan KWJ kepada pengguna media sosial yang lain. Selfie yang dilakukan oleh pengunjung selain meningkatkan eksistensinya juga meningkatkan eksistensi KWJ. Melalui media sosial, KWJ semakin dikenal oleh masyarakat luas. Hal tersebut juga diungkapkan oleh salah satu ibu PKK yang bertugas menjaga tiket di depan pintu masuk KWJ:

“..kami ibu-ibu PKK awalnya tidak mengetahui tentang media sosial. Tetapi kemudian, Guys Pro memperkenalkan KWJ melalui media sosial. Mereka juga mengajari kami menggunakan media sosial untuk memperkenalkan KWJ. Selain itu, pengunjung sendiri yang memperkenalkan $K W J$. Dengan berselfie di salah satu ornamen atau di depan mural yang menurut mereka menarik, kemudian mengunggahnya di media sosial, banyak tanggapan dari para pengguna media sosial. Berawal dari unggahan foto pengunjung, KWJ semakin dikenal oleh masyarakat luas." (Wawancara dengan Ibu Yati pada 15 Agustus 2017).

Saat ini melakukan promosi wisata bukanlah hal yang sulit. Kecanggihan teknologi mempermudah menyebarluaskan berita dan hal-hal baru yang perlu diketahui oleh masyarakat. Saat ini tugas masyarakat lokal KWJ adalah mempertahankan kreativitasnya dan selalu menginspirasi untuk menciptakan kreativitas baru guna menarik minat pengunjung. Lebih lanjut, promosi melalui media sosial, juga menggugah para warga Malang yang merantau di luar kota atau luar pulau mengunjungi KWJ ketika pulang ke Malang. Pada saat observasi, peneliti menemui banyak warga asli Malang mengunjungi KWJ, pada saat liburan hari raya Idul Fitri. Peneliti mengetahui pengunjung adalah orang asli Malang yang merantau, karena para pengunjung sekaligus bersilaturahmi dan sudah kenal dengan penduduk di lingkungan KWJ.

\section{Produk Inovasi Pemuda Mendukung Ket- ahanan Ekonomi Keluarga}

Setelah diresmikan oleh Wali Kota Malang sebagai kampung wisata, Guys Pro gencar mempromosikan KWJ di media sosial dan mengadakan event di lapangan RW 02 Kelurahan Jodipan. Promosi dan kegiatankegiatan semakin hari semakin menarik minat pengunjung untuk datang. Hampir semua rumah membuka rumahnya sebagai tempat berwirausaha. Ada yang menyediakan makanan ringan dan minuman, makanan berat, berjualan kaos dan souvenir khas KWJ, serta berjualan makanan lokal Malang.

Pertama kali peneliti melakukan observasi di KWJ, peneliti mewawancarai tiga orang pedagang yang ada di sana. Pedagang pertama yang diwawancarai menceritakan bahwa ia sudah berjualan sebelum Jodipan dijadikan sebagai DTW. Menurutnya terjadi peningkatan pendapatan setelah Jodipan dijadikan DTW, terutama pada saat weekend dan hari libur. Pedagang kedua yang menjadi informan peneliti adalah Ibu Wiwik. Berikut informasi yang beliau sampaikan. 
“..Saya berjualan setelah Jodipan dijadikan kawasan wisata. Awalnya saya ya di rumah saja tidak ada kegiatan. Tetapi setelah melihat banyak orang datang ke sini, saya jadi mikir kayaknya kalau jualan lumayan. Kalau hari-hari biasa lumayan sekitar 40 ribu sampai 50 ribu pendapatan bersih per hari, tapi pas sabtu, minggu atau hari libur ramai mbak. Biasanya bisa dapat 75 ribu100 ribu per hari. Setelah adanya KWJ, banyak peluang lapangan pekerjaan. Yang jadi tukang parkir di depan itu tetangga saya yang dulu adalah pensiunan sopir. Setelah pensiun tidak bekerja, tetapi saat ini ia bisa mendapatkan penghasilan. " (Wawancara dengan Ibu Wiwik pedagang di KWJ, 15 Mei 2017)

Sejak KWJ dibuka sebagai kawasan wisata, masyarakat merasakan peningkatan kesejahteraan, karena mendapat penghasilan tambahan. Sebagian besar rumah-rumah warga digunakan untuk membuka usaha/retail. Selain itu, ada beberapa warga yang berjualan lapangan. Ibu rumah tangga yang dulunya di rumah tanpa pemasukan keuangan, saat ini mempunyai penghasilan tambahan dengan menjaga tiket masuk. Pengelola memberikan bonus kepada ibu-ibu PKK yang berjaga di tiket jika ada yang berhasil menghabiskan 100 tiket dalam satu hari. Berikut informasi yang disampaikan Ketua RW 02

“Ketua pengelola wisatanya Ketua RT
7 mbak. Kalau yang jaga di tiket masuk
ibu-ibu PKK yang bekerja di rumah. Siapa
yang mau dipersilakan. Kita tidak berani
memaksa. Yaa saat ini lumayan warga
ada pemasukan, membantu mengangkat
perekonomian warga. (Wawancara dengan
Bapak Soni Parin pada 2 Juli 2017)"

Penghasilan masyarakat Jodipan yang berwirausahan di rumahnya sendiri dapat mensejahterakan keluarganya. Masyarakat yang berjualan di rumahnya tidak perlu melakukan pekerjaan lain di luar rumah, karena penghasilan yang didapatkan mampu memberi keuntungan yang dapat digunakan untuk mencukupi kebutuhan keluarganya. Kategori keluarga miskin menurut World Bank (2006) dengan indikator pendapatan per kapita per hari \$1 sampai \$2, atau dalam kurs rupiah sekitar Rp 14.000,- sampai Rp 28.000,- per hari. Berdasarkan hasil penelitian lapangan ketika hari efektif, pendapatan bersih masyarakat sekitar dari berjualan makanan ringan, minuman, makanan lokal, dan souvenir rata-rata Rp 40.000-Rp 50.000 per hari. Di lain pihak pada saat hari libur pendapatannya meningkat sekitar Rp. 75.000 - Rp 100.000,per hari. Oleh karena itu, dapat disimpulkan bahwa inovasi pemuda menciptakan wisata KWJ meningkatkan ketahanan ekonomi keluarga bagi warga RW 02 Kelurahan Jodipan.

Indikator kedua yang digunakan untuk mengukur ketahanan ekonomi keluarga adalah UMK Kabupaten/Kota. Sesuai dengan Pergub No 121 Tahun 2016, UMK Kota Malang tahun 2017 sebesar Rp 2.272.160.50. Apabila dilihat dari besarnya UMK di Kota Malang, pendapatan warga Jodipan yang berwirausaha di rumah dan sekitar KWJ selama satu bulan sekitar Rp 1.400.000,- sampai Rp 1.800.000,-Dapat disimpulkan bahwa pendapatan bersih masyarakat Jodipan jika diukur dengan menggunakan UMK Kota Malang masih berada di bawah UMK. Namun, jika indikator yang digunakan masyarakat adalah filosofi Jawa "jangan besar pasak daripada tiang", maka berapapun pendapatannya pengeluaran tidak boleh melebihi pendapatan. Sebagai ilustrasi, jika seorang warga Jodipan memiliki penghasilan bersih Rp 1.400.000,- sampai Rp 1.800.000,- maka kebutuhan sandang, pangan, papan, dan kebutuhan anak sekolah menyesuaikan dengan pendapatan tersebut. 


\section{SIMPULAN}

Berdasar penjelasan tersebut di atas dapat ditarik simpulan sebagai berikut.

Pertama, sektor pariwisata yang dikembangkan memberikan multiplier efek kepada masyarakat sekitar yang tinggal di DTW. Pemuda memiliki andil besar dalam pembangunan bangsa. Salah satunya yang dilakukan oleh Guys Pro (Mahasiswa Ilmu Komunikasi UMM). Mereka mempunyai ide yang bermanfaat guna mengangkat perekonomian masyarakat. Guys Pro melakukan komunikasi dengan warga untuk mewujudkan idenya. Untuk mengubah kawasan kumuh Kampung Jodipan, tindakan komunikatif yang dilakukan oleh Guys Pro adalah dengan menerapkan teori tindakan komunikatif Jurgen Habermas. Komunikasi dilakukan tidak hanya kepada warga yang berhak membuat kebijakan. Guys Pro melakukan komunikasi dengan Ketua RW, kemudian Ketua RT, yang selanjutnya dengan warga masyarakat. Masyarakat menyetujui perkampungannya dicat, dan dijadikan sebagai kampung warna-warni. Masyarakat menerima ide dari Guys Pro untuk mengubah kampung kumuh Jodipan menjadi DTW. Hal ini menunjukkan bahwa masyarakat bersedia menerima perubahan tatanan baru, salah satunya harus menjaga kebersihan.

Kedua, KWJ memberikan banyak manfaat kepada masyarakat sekitar, sehingga perekonomian masyarakat sekitar terangkat. Banyaknya kunjungan wisata memberikan motivasi kepada masyarakat untuk membuka usaha di rumahnya sendiri. Kegiatan yang dilakukan oleh masyarakat sekitar, antara lain membuka usaha di rumah dan menjadi pengelola KWJ.Masyarakat bersedia menerima wilayahnya menjadi kampung wisata. Penerimaan tersebut terlihat dengan semangatnya dalam beraktivitas mendukung kelangsungan DTW KWJ. Kegiatan ekonomi masyarakat di KWJ berhasil mendukung ketahanan ekonomi warga RW 02 Kelurahan Jodipan.

Ketiga, semakin hari semakin banyak warga yang menyediakan makanan ringan untuk pengunjung dengan berbagai variasi olahan. Pendapatan warga perhari lebih besar dari indikator yang digunakan oleh World Bank untuk kategori keluarga miskin. Walaupun pendapatan warga lebih rendah daripada UMK Kota Malang, tetapi sesuai prinsip orang Jawa, seberapapun pendapatannya maka jangan sampai melebihi pengeluaran yang dikeluarkan guna mencukupi kebutuhan sehari-hari.

\section{DAFTAR PUSTAKA}

Abdullah, Taufik (Ed)., 1974, Pemuda dan Perubahan Sosial, Jakarta: Penerbit LP3ES.

Anoraga, P \& Widiyanti, N., 1993, Dinamika Koperasi, Bandung: Rineka Cipta.

Dhont, Frank., 2005, Nasionalisme Baru Intelektual Indonesia Tahun 1920-an, Yogyakarta: UGM Press.

Haryati, Sri, 2016, "Peran Pemuda dalam Mengelola Kawasan Ekowisata dan Implikasinya terhadap Ketahanan Masyarakat Desa (Studi tentang Pemuda Pengelola Desa Wisata Kandri, Kecamatan Gunung Pati, Kota Semarang, Provinsi Jawa Tengah)", dalam Jurnal Ketahanan Nasional, Vol. 22 No. 2 edisi Agustus 2016, Hal. 117-136, P-ISSN: 0853-9340, e-ISSN: 2527-9688.

Ibrahim, A., 2006, Model Ketahanan Nasional Sebagai Administrasi Negara Untuk Memberdayakan Otonomi Daerah, Bandung: Mandar Maju. 
Irfaan, Santoso., 2009., "Jurgen Habermas: Problem Dialektika Ilmu Sosial", dalam Jurnal Dakwah dan Komunikasi "Komunika", Vol.3 N0. 1 Januari-Juni 2009 pp. 101-113, ISSN: 1978-1261, Purwokerto: Jurusan Dakwah STAIN Purwokerto.

Lemhannas, 1997, Ketahanan Nasional, Jakarta: Balai Pustaka-Lemhannas.

Muljadi, A.J. \& Warman, A., 2014, Kepariwisataan dan Perjalanan, Jakarta: Raja Grafindo Persada.

Nurhayati, Aniek., 2016, Membangun dari Keterpencilan (Soft Constructivism, Kesadaran Aktor dan Modernitas Dunia Pesantren di Pedesaan), Jakarta: Daulat Press.

PU Kota Malang, 2014, Profil Kawasan Kumuh Kota Malang, Laporan tidak diterbitkan.

Pimpinan Pusat Muhammadiyah, 23 Juli 2016, "Mahasiswa UMM di Balik Indahnya Warna-Warni Jodipan-Malang", http:// www.muhammadiyah.or.id/id/news/ pdf/6748/mahasiswa-umm-di-balikindahnya-warna-warni-jodipanmalang. html, diunduh pada 15 JUui 2017.

Raditya, Michael HB., 2014, "Selfie dan Media Sosial pada Seni sebagai Wujud Eksistensi”, dalan Jurnal Ilmu Sosial dan Ilmu Politik (JSP), Volume 18 Nomor 1 Juli 2014, hal. 26-38, ISSN: 1410-4946.

Santosa, 2011, "Multiplier Efek Kampung Industri Kasongan", dalam Jurnal AMPTA, diunduh di amptajurnal.ac.id/index.php/ MWS/article/download/51/50, pada 15 Agustus 2017.

Saryani, 2013, "Pariwisata dan Ketahanan Sosial Budaya", dalam Jurnal Ketahanan Nasional, Vol. XIX No. 1 edisi April 2013, Hal. 47-55.
Satries, Wahyu Ishardino., 2009, "Peran Serta Pemuda dalam Pembangunan Masyarakat", dalam Jurnal Madani, Vol 9 No. 1 Edisi Mei 2009, Bekasi: FISIP Universitas Islam Bekasi, diunduh dari http://ejournal-unisma. net/ojs/index.php/madani/issue/view/49/ showToc, pad 30 September 2017.

Sulistiawati, 2013, "Partisipasi Masyarakat dalam Pelaksanaan PNPM Mandiri Perdesaan dan Efektifitasnya Terhadap Ketahanan Ekonomi Keluarga (Studi di Kecamatan Kalanganyar, Kabupaten Lebak, Banten)", dalam Jurnal Ketahanan Nasional, Vol XIX No. 2 edisi Agustus 2013, Hal. 90-97.

Suyanto, Bagong dan Amal, M. Khusna., 2010, Anatomi Dan Perkembangan Teori Sosial, Malang: Aditya Media Publishing. Surya, 5 September 2016, "Kampung WarnaWarni di Kota Malang Jadi Pilot Project Kampung Wisata", diunduh dari http:// keljodipan.malangkota.go.id/2016/09/05/ kampung-warna-warni-di-kota-malangjadi-pilot-project-kampung-wisata/ pada 10 September 2017.

Widianto, Eko., 16 Oktober 2016, "Kampung Warna-Warni" Malang, Dulu Kumuh Sekarang Jadi Tempat Wisata", diunduh dari www.bbc.com pada tanggal 10 September 2017.

Wulandari, Prisca Kiki., 2015, "Peran pemuda dalam Memperkenalkan Industri Kepariwisataan dan Implikasinya terhadap Ketahanan Ekonomi Wilayah", dalam Tesis, Sekolah Pascasarjana Universitas Gadjah Mada.

Wulandari, Prisca Kiki, Destriana Saraswati, Surya D.E Putra., 2017, Membangun Indonesia: Pemberdayaan Pemuda Berwawasan Pancasila, Malang: UB Press 
Prisca Kiki Wulandari -- Inovasi Pemuda Dalam Mendukung Ketahanan Ekonomi Keluarga (Studi Di Kampung Warna-Warni Kelurahan Jodipan, Kecamatan Blimbing, Kota Malang)

Zulkarnain, Muhammad Iskandar., 2015, "Peran Balai Pemuda dan Olahraga Yogyakarta dalam Upaya Pengembangan Kewirausahaan Pemuda Untuk Mendukung Ketahanan Ekonomi Keluarga (studi tentang Persepsi Peserta Kegiatan Pelatihan Keterampilan BPO DIY)", dalam Jurnal Ketahanan Nasional, Vol.21 No. 3 Edisi Desember 2015, Hal. 197-207.

\section{Internet}

http://komunikasi.umm.ac.id suryamalang.tribunnews.com

\section{Peraturan Perundangan}

Undang-Undang No 40 Tahun 2009 tentang Kepemudaan

Peratruran Gubernur No.121 Tahun Tentang UMK

\section{Wawancara}

1. Bapak Soni Parin (Ketua RW 02 Kelurahan Jodipan)

2. Nabila Firdausiyah (Ketua Guys Pro, Pencetus ide KWJ).

3. Ibu Wiwik, Pedagang di KWJ.

4. Ibu Yati, pengelola KWJ. 